\title{
Method for the automatic determination of serum iron
}

\author{
D.S. YOUNG AND JOCELYN M. HICKS \\ From the Department of Chemical Pathology, Postgraduate Medical School, \\ London
}

SYNOPSIS A simple method is described for the automated determination of serum iron and tota iron-binding capacity, which eliminates the need to render apparatus or reagents iron-free. Tipe method is faster than normal procedures and its accuracy is comparable with other accepted methods for the determination of serum iron.

The available methods for the determination of serum iron are time-consuming and require iron-free glassware. A method which avoids these drawbacks of the conventional serum iron methods and greatly simplifies the determination of serum iron is described here. By using standard components of the AutoAnalyzer system of Technicon Instruments Company Ltd., it is possible to determine both serum iron and total iron-binding capacity colorimetrically without special precautions to make either the apparatus or reagents iron-free. 2,4,6Tripyridyl-1,3,5-triazine is used as colour-developing reagent because of the high molecular coefficient of absorption of its complex with iron in water (Diehl and Smith, 1960). In spite of the simplicity of the method the results compare very favourably with non-automated methods using both tripyridyl and tripyridyl-triazine as complexing agents.

\section{METHOD}

PRINCIPLE Iron is simultaneously released from protein and reduced by hydrochloric acid and ascorbic acid. The reduced iron is separated from the protein by dialysis and allowed to react with tripyridyl-triazine. The complex formed is measured colorimetrically at a controlled $p \mathrm{H}$. A flow diagram of the method used showing the components of the AutoAnalyzer required is illustrated in Figure 1.

\section{REAGENTS}

SAMPLE DILUENT Ascorbic acid, 1 g., is dissolved in $100 \mathrm{ml}$. of $0.1 \mathrm{~N} \mathrm{HCl}$ with 12 drops of $20 \%$ Tween 20 added per litre.

Received for publication 6 July 1964.
RECIPIENT SOLUTION 2,4,6-Tripyridyl-1,3,5,triazine' mg., is dissolved in $100 \mathrm{ml} .0 \cdot 1 \mathrm{~N} \mathrm{HCl}$ with 6 drops $20 \%$ Tween 20 added per litre.

ALKALINE SOLUTION Ammonium acetate, 10 g., . TS dissolved in $100 \mathrm{ml}$. of water.

DISTILLED WATER This is prepared by steam condeg sation followed by passage through a mixed-bed iôn exchange resin.

IRON STANDARDS For the stock solution containing $5 \mathrm{~m}$. of iron per ml., dissolve $4 \cdot 32 \mathrm{~g}$. of ferric ammonium sulphate in water, add $10 \mathrm{ml}$. of concentrated hydrochloric ack, and make to a final volume of $100 \mathrm{ml}$. with water. Working standards containing 50,100, 200, 300, 400, a a $500 \mu \mathrm{g}$. per $100 \mathrm{ml}$. are prepared from the stock solution by dilution with distilled water.

Analytical grade reagents are used where available. 鵻 standards must be prepared and stored in iron-free glassware. Distilled water also should be stored iron-free containers but this is not necessary for the reagents. AutoAnalyzer cups are sufficiently iron-free to be used without further treatment.

Samples may be analysed at a rate of up to 60 per hoū. but alternate cups should contain water to ensure on adequate wash. Either a $10 \mathrm{~mm}$. cuvette or a $15 \mathrm{~mm}$. tubular flow-cell may be used in the colorimeter but the latter is preferable because of the greater sensitivfey obtained. If the flow cell is used the sample must $\mathbb{B e}$ drawn through the cell by means of the purple coded tube shown in Figure 1. The ferrous iron tripyridf triazine complex has a maximum absorption at $593 \mathrm{nf} \mathrm{fu}_{\mu}$ but as no filters of this wavelength were available, $600 \mathrm{~m}$ filters were used and found to be satisfactory. Due to the shape of the absorption spectrum of the complex and tite quality of filters available, it is unlikely that the use 欠ै $^{f}$ $593 \mathrm{~m} \mu$ filters would significantly improve the sensitivay of the method. 


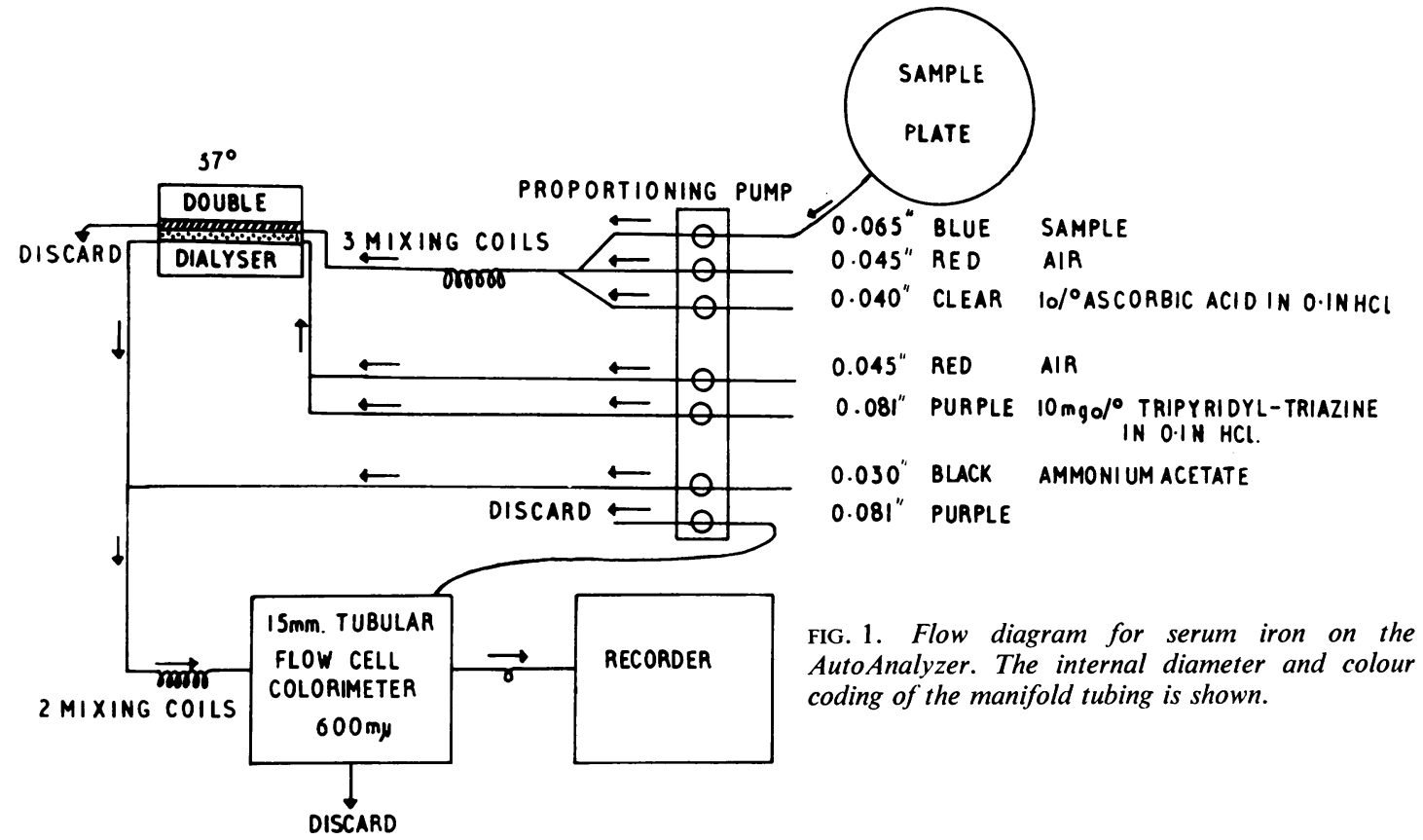

It is essential, when setting up the apparatus after other analyses have been performed, to pump reagents through the manifold with the sample-line in distilled water to make the apparatus iron-free. When the system is iron-

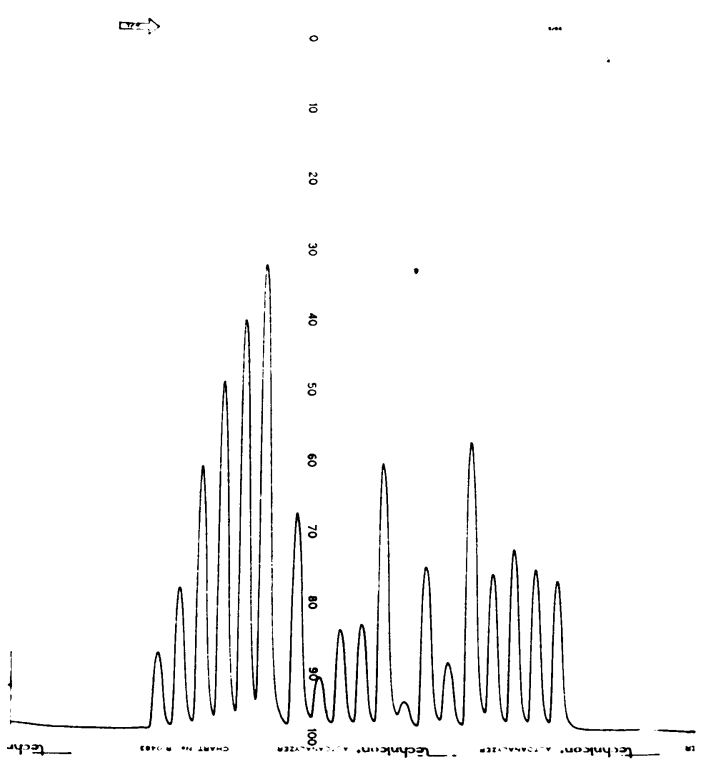

FIG. 2. Photograph of actual AutoAnalyzer recorder tracing with six standards from 50 to $500 \mu \mathrm{g}$. iron per $100 \mathrm{ml}$. and 13 tests. free the base-line on the recorder should be a continuous straight line. It is important that its position should be determined while the apparatus is sucking reagents. In order to prevent contamination from dust it is advisable to place a cover on top of the sample plate.

Standards with iron concentrations up to $500 \mu \mathrm{g}$. per $100 \mathrm{ml}$. are run with each batch of sera to ensure that even sera with a high iron content following an iron absorption test do not have to be diluted. The spread of the standards with each run should be similar to that shown in a typical AutoAnalyzer tracing (Fig. 2).

The procedure of Ramsay (1957b) is followed for determination of the total iron-binding capacity. $2 \mathrm{ml}$. of a solution containing approximately $500 \mu \mathrm{g}$. ferric iron per $100 \mathrm{ml}$., is added to $1 \mathrm{ml}$. of serum in a centrifuge tube and the solutions mixed. After $5 \mathrm{~min}$. approximately $200 \mathrm{mg}$. 'light' magnesium carbonate is added. The tube is covered with Parafilm (A. Gallenkamp \& Co. Ltd., London, E.C.2) and is thoroughly shaken at intervals for the next 30 to 60 minutes. The tube is then centrifuged at 3,000 r.p.m. for 5 min., and a portion of the supernatant fluid is decanted into an AutoAnalyzer cup and estimated as for serum iron. The total iron-binding capacity is then three times the value calculated from the AutoAnalyzer recorder chart.

\section{RESULTS}

The accuracy of the method using the AutoAnalyzer was assessed by making comparisons with a nonautomated method using tripyridyl as chromogen (King and Wootton, 1956) and another non- 


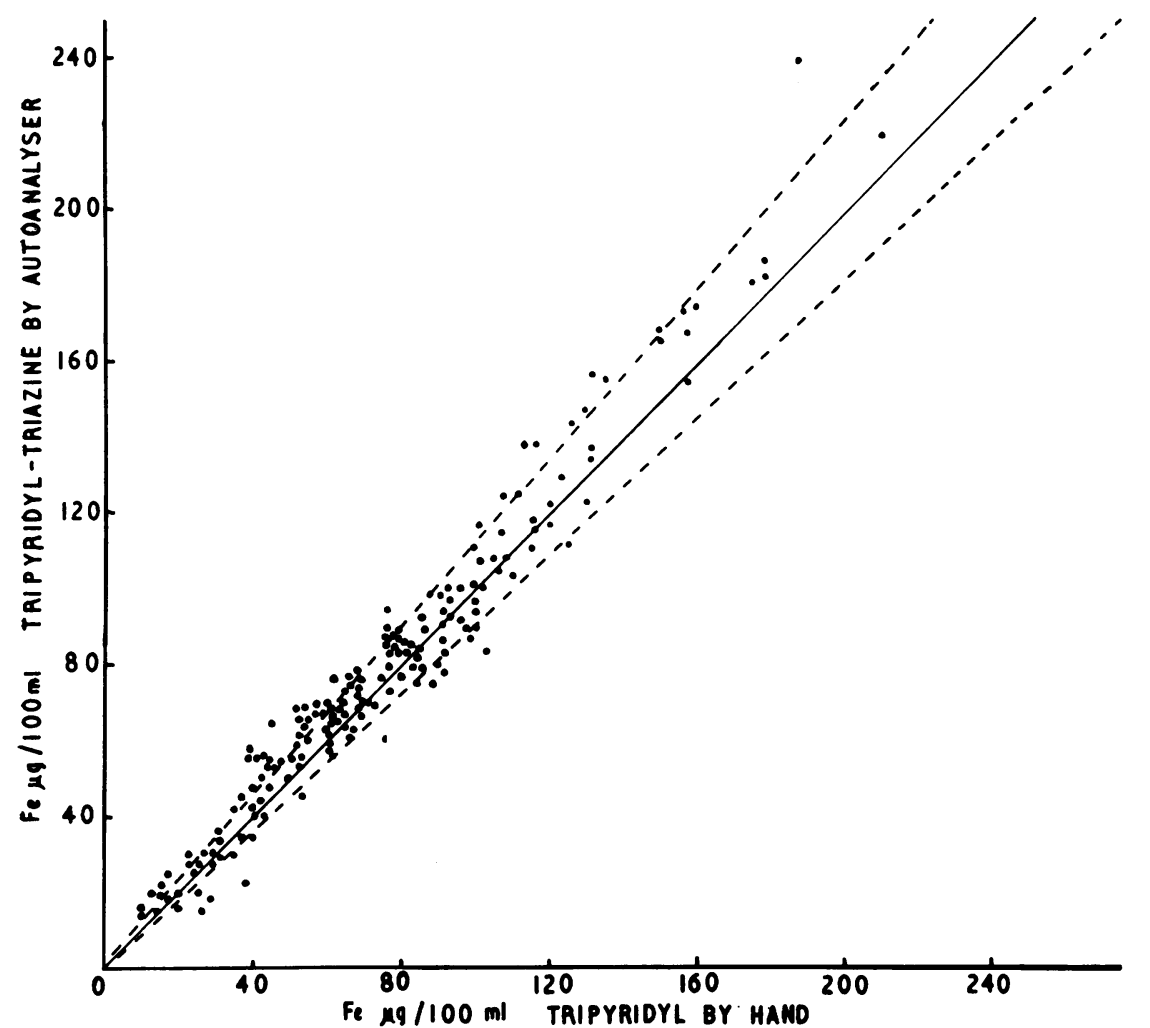

FIG. 3. Comparison between 205 serum iron values obtained by the AutoAnalyzer and a manual tripyridyl method.

The solid line represents complete agreement between the two methods.

The dotted lines represent deviations of $\pm 10 \%$ from this.

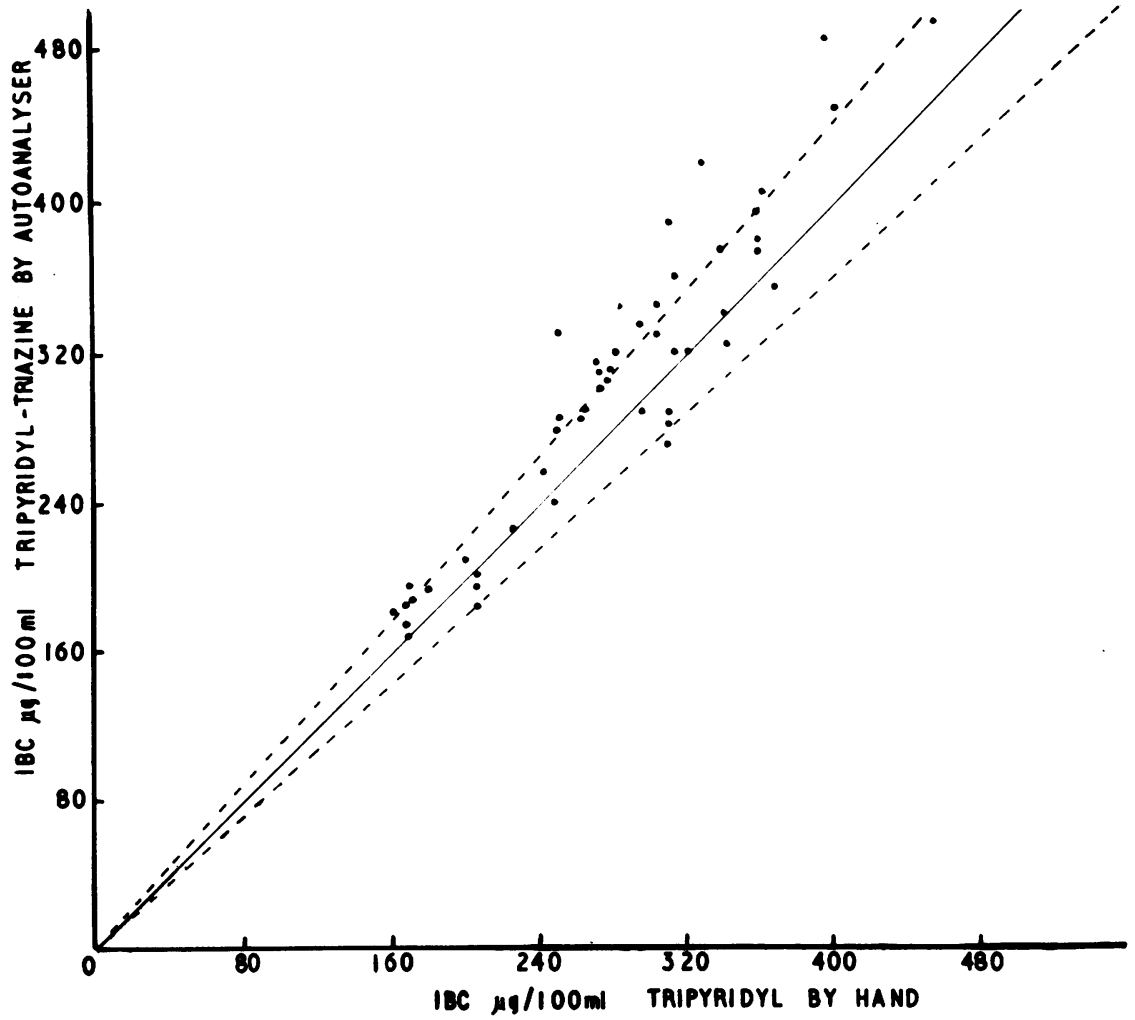

FIG. 4. Comparisoฌ̂ between 55 serum total iron-binding capacity values obtained by the AutoAnalyzer and manual tripyridyl method. 
automated method using tripyridyl-triazine (Caraway, 1963). The results of 205 successive analyses measured by both the AutoAnalyzer and the manual tripyridyl methods are plotted on a scatter diagram (Fig. 3). It shows that there is good agreement between the two methods over the range of serum iron concentrations tested, although there is a tendency for the AutoAnalyzer answers to be higher than the tripyridyl answers. This tendency is exaggerated when the iron-binding capacities, as determined by the two methods, are compared (Fig. 4). This difference, however, may be due to the complexing agent used, because Caraway (1963) has shown that tripyridyl-triazine also yields higher answers than dipyridyl, and dipyridyl and tripyridyl have been found in this laboratory to give similar results. A comparison of hand and machine methods using tripyridyl-triazine showed that the former, on average, produced a slightly higher answer.

REPRODUCIBILITY A serum pool was analysed 47 times. The mean value found was $100 \mu \mathrm{g}$. per $100 \mathrm{ml}$. with a range of 94 to $106 \mu \mathrm{g}$. per $100 \mathrm{ml}$. and a standard deviation of $2 \cdot 3 \mu \mathrm{g}$. per $100 \mathrm{ml}$. Fortyeight serum samples, with iron values ranging from 26 to $344 \mu \mathrm{g}$. per $100 \mathrm{ml}$, were analysed on two occasions. The standard deviation of the series was found to be $2.9 \mu \mathrm{g}$. per $100 \mathrm{ml}$.

\section{TABLE I}

RECOVERY EXPERIMENTS USING THE AUTOANALYZER

$\begin{array}{lll}\text { Theoretical } & \text { Duplicate } & \text { Percentage } \\ \text { Value } & \text { Deter- } & \text { Recovery } \\ (\mu g . / 100 & \text { mined } & \\ \text { ml. }) & \text { Values } & \\ & (\mu g . / 100 \\ & \text { ml. }) & \end{array}$

Distilled water, $5 \mathrm{ml}$. with

$0.1 \mathrm{ml} .500 \mu \mathrm{g} . / 100 \mathrm{ml}$. std. added

$0.2 \mathrm{ml} .500 \mu \mathrm{g} . / 100 \mathrm{ml}$. std. added

$0.5 \mathrm{ml} .500 \mu \mathrm{g} . / 100 \mathrm{ml}$. std. added

$1.0 \mathrm{ml} .500 \mu \mathrm{g} . / 100 \mathrm{ml} . \mathrm{std}$. added

Serum Pool $5 \mathrm{ml}$, with $0.1 \mathrm{ml}$. high serum $A$ added $0.2 \mathrm{ml}$. high serum $A$ added $0.5 \mathrm{ml}$. high serum $A$ added $1.0 \mathrm{ml}$. high serum $A$ added

Serum Pool $5 \mathrm{ml}$. with

$0.1 \mathrm{ml}$. high serum $B$ added $0.2 \mathrm{ml}$. high serum $B$ added $0.5 \mathrm{ml}$. high serum $B$ added

Serum Pool $5 \mathrm{ml}$. with

$0.25 \mathrm{ml}$. high serum $\mathrm{C}$ added

$1.0 \mathrm{ml}$. high serum $C$ added

$2.0 \mathrm{ml}$. high serum $C$ added

$3.0 \mathrm{ml}$. high serum $C$ added
RECOVERY EXPERIMENTS The aqueous standards were diluted with solutions containing known concentrations of iron and sera with known iron concentrations were similarly treated. Other sera were diluted with sera containing a high concentration of iron and the concentrations found were compared with the theoretical concentration. The recoveries were satisfactory as is shown by some representative examples in Table I.

\section{DISCUSSION}

This method for determining serum iron has the advantage over other methods that no glassware has to be free of iron except for the syringe which is used to take the blood and the container to which it is transferred. This method is also rapid because up to 30 tests may be analysed each hour. Standard components of an AutoAnalyzer are used which means that most large biochemical laboratories could use this method without any additional equipment.

Though the method was found equally applicable to serum or heparinized plasma, it is unsuitable for specimens in which E.D.T.A. has been used as anticoagulant because E.D.T.A. forms a stable chelate with iron. Like many other methods (Nissim, 1953; Ramsay, 1957a) the AutoAnalyzer method is unsuitable for use on plasma containing Dextran because falsely low answers result. Haemolysis has a negligible effect on the iron values recorded by this method. The iron values recorded were unaffected by turbidity, lipaemia, or high bilirubin concentrations in the sera. It was found possible to obtain satisfactory answers on sera with a high protein content which caused marked turbidity at the final stage of the King and Wootton (1956) procedure and produced falsely high results. Storage of sera at $4^{\circ} \mathrm{C}$. or at $-20^{\circ} \mathrm{C}$. for two weeks had no effect on the serum iron as determined by the present method.

Though Ramsay (1957a) has claimed that a concentration of $1.0 \mathrm{~N} \mathrm{HCl}$ is necessary to extract all the iron from all sera, a concentration of only one-tenth of this is used in the present method. Higher concentrations tended to precipitate protein and it was found that recoveries were satisfactory with the lower concentration. The conditions used in the automated procedure are similar to those employed in the initial stages of the Caraway (1963) procedure. Caraway showed that variations of ascorbic acid concentrations between 1 and $5 \%$ and hydrochloric acid concentrations up to $0.6 \mathrm{~N}$ had no effect on the final result. In Caraway's procedure, serum is incubated for five minutes but in the present study a shorter incubation is compensated for by continuous mixing of serum and acid. 
Iron methods which utilize protein precipitation have been criticised on the grounds that some iron may be trapped in the precipitate (Peterson, 1953). The use of strong acid to liberate iron from the iron-binding protein has been further criticised because pigments may be liberated which might significantly increase the apparent iron concentration (Rosenthal, Pfluke, and Jud, 1958). This is especially true when trichloroacetic acid is used to precipitate proteins as in the Ramsay (1957a) procedure (Henry and Berkman, 1957).

Methods for estimating iron which do not employ extraction of a coloured iron complex into an organic solvent may give a falsely high answer because of the presence of pigments (Peters, Giovanniello, Apt, and Ross, 1956). This may be overcome to some extent by the use of controlblanks, as in the procedures of Levy and Vitacca (1961) and Sanford (1963) but this further complicates the estimation of the serum iron. The problem is overcome by the use of dialysis in the present procedure.

The large number of available iron methods, with widely differing values for the normal range of the serum iron, suggests that many of the methods are inadequate. The close agreement between this method and Caraway's (1963) method would mean that his range of 65 to $150 \mu \mathrm{g}$. per $100 \mathrm{ml}$. would be applicable to the automated method. No attempt has been made to establish another normal range with the present method. The estimation of the serum iron and iron-binding capacity is often neglected by laboratories because of the technical difficulties estimating iron reliably. The automated procedure using tripyridyl-triazine is extremely simple an rapid. Its accuracy is comparable with other accepted methods. Use of the automated procedure shout therefore enable hospital laboratories to undertake many more analyses of serum iron and iron-binding capacity, which would be of considerable value the investigation of cases of anaemia.

We are very grateful to Professor I. D. P. Wootton for his advice and criticism. We would also like to thang Mr. L. J. Evans and Dr. H. W. Holy of Technicoxit Instruments Company for their cooperation and loan of equipment, and Dr. Eileen Harriss who performes many of the tripyridyl-triazine tests by hand.

\section{REFERENCES}

Caraway, W. T. (1963). Clin. Chem., 9, 188.

Diehl, H., and Smith, G. F. (1960). The Iron Reagents: Bathophena. throline, 2,4,6-Tripyridyl-s-triazine, Phenyl-2-pyridyl ketoxinf G. F. Smith Chemical Company, Columbus, Ohio.

Henry, R. J., and Berkman, S. (1957). Clin. Chem., 3, 711.

King, E. J., and Wootton, I. D. P. (1956). Microanalysis in Medicet Biochemistry, Churchill, London.

Levy, A. L., and Vitacca, P. (1961). Clin. Chem., 7, 241.

Nissim, J. A. (1953). Brit. J. Pharmacol., 8, 371.

Peterson, R. E. (1953). Analyt. Chem., 25, 1337.

Peters, T., Giovanniello, T. J., Apt, L., and Ross, J. F. (1956). J. La clin. Med., 48, 280.

Ramsay, W. N. M. (1957a). Clin. chim. Acta, 2, 214

- (1957b). Ibid., 2, 221.

Rosenthal, H. L., Pfluke, M. L., and Jud, L. (1958). Clin. Chem., 290.

Sanford, R. (1963). J. clin. Path., $16,174$. 